\title{
Energy requirement for Kharif maize cultivation in Panchmahal district of Gujarat
}

\section{P.G. PATEL, RANGAPARA DINESHKUMAR AND A.C. BHUT}

Received : 08.02.2017; Revised : 17.03.2017; Accepted : 25.03.2017

See end of the Paper for authors' affiliation

Correspondence to :

RANGAPARA

DINESHKUMAR

Sardar Patel Renewable

Energy Research Institute,

Vallabh Vidhyanagar, ANAND

(GUJARAT) INDIA

Email : dineshrangapara@

gmail.com
- ABSTRACT : A study was carried out to collect farm operations data of Kharif maize cultivation in district Panchmahal of Gujarat and to estimate and analyze the total input energy requirement in Kharif maize crop, both source wise and operation wise along with total output energy. To accomplish this, a survey was conducted through structured questionnaire to 93 randomly selected farmers in four rainfed villages of three talukas Kalol, Godhra and Khanpur of the district. The raw data obtained was analyzed after converting data into energy equivalents. It was concluded that total input energy requirement for Kharif maize cultivation in Panchmahal district was 13205.10 $\mathrm{MJ} / \mathrm{ha}$. Out of which direct energy contributed 45.44 per cent and indirect energy contributed 54.56 per cent. Fuel energy was maximum utilizing direct energy source while fertilizer energy was maximum required indirect energy source. Seed bed preparation consumed maximum operation wise direct energy with a value of $2887.78 \mathrm{MJ} / \mathrm{ha}$. Fertilizer application was maximum indirect energy consuming operation with energy consumption of $3702.59 \mathrm{MJ} / \mathrm{ha}$. Total output energy for Kharif maize cultivation was $52873.29 \mathrm{MJ} / \mathrm{ha}$ with net energy return of $39668.19 \mathrm{MJ} / \mathrm{ha}$ and energy productivity of $0.21 \mathrm{~kg} / \mathrm{MJ}$.

- KEY WORDS : Energy, Kharif, Maize, Specific energy

-HOW TO CITE THIS PAPER : Patel, P.G., Dineshkumar, Rangapara and Bhut, A.C. (2017). Energy requirement for Kharif maize cultivation in Panchmahal district of Gujarat. Internat. J. Agric. Engg., 10(1) : 146-151, DOI: 10.15740/HAS/IJAE/10.1/146-151. 